\title{
A Tuberculoid Leprosy Case with Ulcers of her Patches
}

\author{
Seitaro OKADA, Shinzo IZUMI, Eirchi NAKAI and Mitsugu NISHIURA \\ (Leprosy Research Laboratory, Kyoto University School of Medicine) \\ HIDEO TAKIZAWA \\ (National Sanatorium Kuryu Rakusen-en) \\ AKIKo OBARA and KAZUKO SUGIYAMA \\ (National Sanatorium Oshima Seisho-en) \\ MOTOAKI OZAKI \\ (National Santorium Nagashima Aisei-en)
}

A female case 56 years old had the variously sized erythemata on her face, neck, buttock, and extremities. They were from coin-sized to twice the size of palm. Some patches had the apparently normal area in their inner part. In addition to those erythemata, the papules which were from marking-pin-head-sized to lens-sized, well-defined, hemispherically raised, and hard were scattered on the back of both hands, fingers, lower arms, legs, and neck.

The macroscopical findings that the skin lesions were multiple, some eruptions were small in size, and some patches had the punched-out appearance suggested us the borderline nature of skin lesions. But the skin biopsy revealed the typical tuberculoid features. The bacteriological examination of skin lesions were negative, and the Mitsuda-test was positive. The small dosis of CIBA 1906 was given to her every day, except for the $1 \mathrm{st}$ week when CIBA 1906 was given 5 days a week. About 5 weeks after the start of chemotherapy, the remarkable desquamation appeared on the patches of legs. And about 4 weeks later, two ulcers came out on the patches of the right leg. Thereafter, the ulcers expanded gradually, and new other ulcers appeared on both legs. About 3 months after the start of chemotherapy, the drug was changed from CIBA 1906 to DDS. But the ulcers did not improve. By the suspicion of skin tuberculosis, INH and PAS were administered, but they had no effect. The biopsy of a nerve which was enlarged revealed the tuberculoid change in the nerve. This result decided that she had the leprosy. Besides, the skin reaction against PPD was not positive, and the cultivation of tubercle bacilli from a eruption was negative. And also the comparative study of macroscopical and microscopical findings of skin eruptions denied the combination of skin tuberculosis. The mycotic dermatitis, syphilis. and the ulcer caused by Mycobacterium ulcerans were denied, too. Thus, it was fixed that they were the ulcers which came out on the leprous tuberculoid patches. About 6 months after the appearance of ulcers, they were cured.

The literatures on the lazarine leprosy were reviewed in this paper. This case is similar to neither Mexican type of lazarine leprosy nor Cuban type, and similar to the cases reported by Ryrie, and Ota and Sato.

The term "lazarine leprosy" should not be used hereafter, because many confusions 
arose concerning the interpretation of "lazarine leprosy". The terms "Lucio's leprosy" and "Pachá's leprosy" should be used. The former means the spotted leprosy with ulcers in diffuse lepromatous case reported first by Lucio, and the latter expresses the monosymptomatic case having destructive ulcer reported first by Pachá.

\title{
皮疹部に潰瘍を発生した類結核らいの 1 例
}

\author{
岡田誠太郎和泉真 蔵 \\ 中井栄一西占貢 \\ (京都大学医学部皮膚病特別研究施設) \\ 滝沢英夫 \\ (栗生楽泉園) \\ 小原安喜子杉山和子 \\ （大島青松園） \\ 尾崎 元 昭 \\ （長島愛生園）
}

（受付 1977 年 7 月29日）

\section{緒 言}

類結核性の病変が神経では往々乾酪様変性に類似した 壊死栄を形成し, 時に神経膿瘍といら状態を呈すること は古くから知られ, 我が国でも塩田1), 小笠原2), 太田・ 佐藤 ${ }^{3)}$, 宗内 ${ }^{4)}$, 佐藤 ${ }^{5)}$, 犀川(67), 平島 ${ }^{8)}$ らの報告があ り，佐藤9は日本における神経膿瘍の報告の一覧表を書 いている。しかし皮疹部において壊死巣を形成すること は稀で, 殊に肉眼的な潰瘍を形成することは極めて稀 で, 佐藤もその著書「瀬」に「皮膚結核との鑑別は, 癩 疹の結核様変化では壊疽を作らず…」と記している。 ただ佐藤は太田との共著による論文「癩の結核様変化に 就いて」3゙に, 皮疹の表面の大部分が潰瘍に陥り，一見ゴ ム腫または皮膚結核の如くであった 1 例を報告してい る。その例はピルケ反応, 口氏反応共に陰性, 皮疹の一 部を乳剤として天竺鼠に接種したが陰性の成績であった という。同論文中にはもう1例浸潤性紅斑のうちあるも のが潰瘍を形成したといら例が記されている。しかし同 論文中にも全般的の傾向として「皮疹では乾酪様変化を みることは殆んどなく, 壞疽はあっても軽度で云うに足 りない」とのべ, またのちの論文中にも「組織像で結核
と異なる点は乾酪様変化を作らぬことで, たとえ壊疽を つくるも極めて微々たるもので言うに足りない」とのべ ている。Lowe ${ }^{10}$ は神経らいに打ける斑紋の研究につい ての論文中の病理学の頂の C) the thick red macule の項に, 「乾酪様変性に陥ることがあり, 皮膚の潰瘍が 生ずることがある」とかいているが, thick red macule はより急性であり菌がより無数にあると書いてあり, 病 型分類にやや問題があり，この論文の標題にも「神経ら いに㧍ける斑紋の研究」という言葉が使ってあり, 潰瘍 を生じたという症例が, 病型的に真の tuberculoid であ ったかどうか疑わしい。

皮疹における潰瘍については, lazarine leprosy につ いてふれなければならない。これについては後の考察の 項に詳しくふれる。Ryrie ${ }^{11) の}$ 報告した類結核らいで皮 疹部に潰瘍を発生した例は, lazayine leprosy とはやや 異なっており，今回著者らが経験した症例に似ている が,これも lazarine leprosy についての考察のところ でふれたい。

\section{症例}

F. Y. 女性, 56歳。職業はホテル従業員, 住所奈良県。 


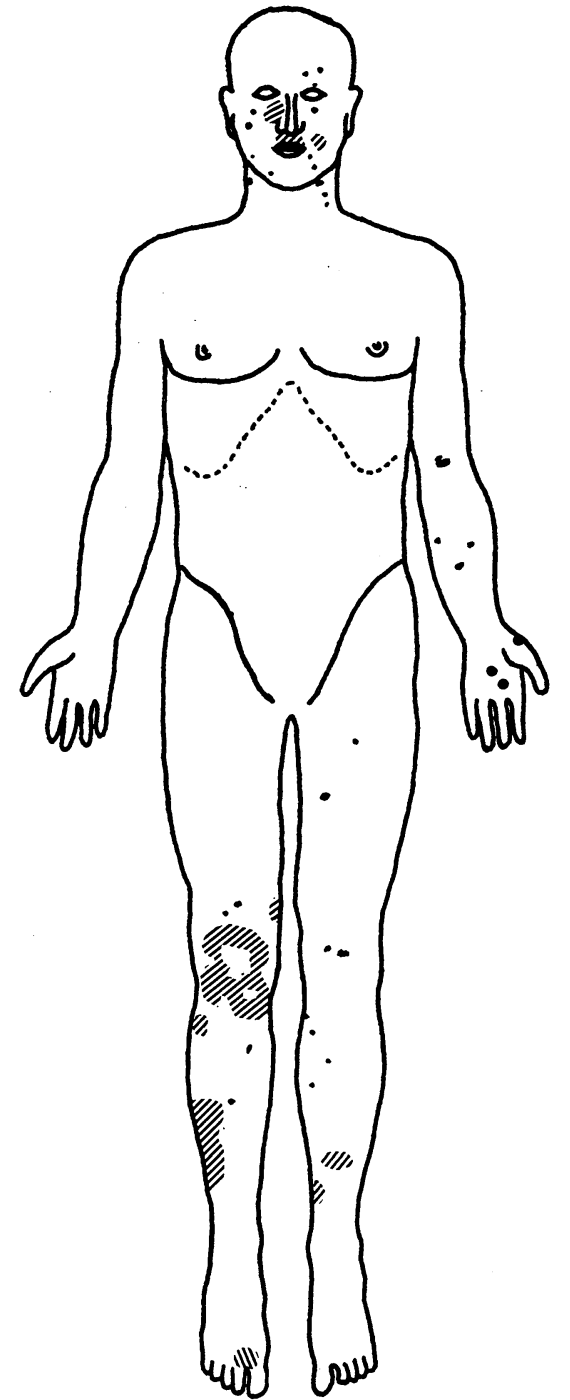

Fig. 1 a Distribut!on of leprous eruptions at the time of admission

幼小児時代麻疹の他に特記すべき疾患の既往なし。そ の後も特になく，50歳頃から本態性高血圧症といわれ， 時々頭痛があった。昭和 50 年 1 月下口唇に米粒大の隆起 した紅斑が生じ，次第に顔面の他の部分にも紅斑が現わ れ，それらが次第に大きくなった。そしてさらに四肢に も生じてきた。3 月に某病院の皮膚科で受診した。4 月 に近くの皮膚科医を訪れ，その後も屡々通院したが，余 り変化がなかった。4 月はじめから四肢のしびれ感があ り，5 月26日再び某病院の皮膚科を訪れ，バイオプシー をうけ，その結果本施設に紹介され，5 月31日本施設初

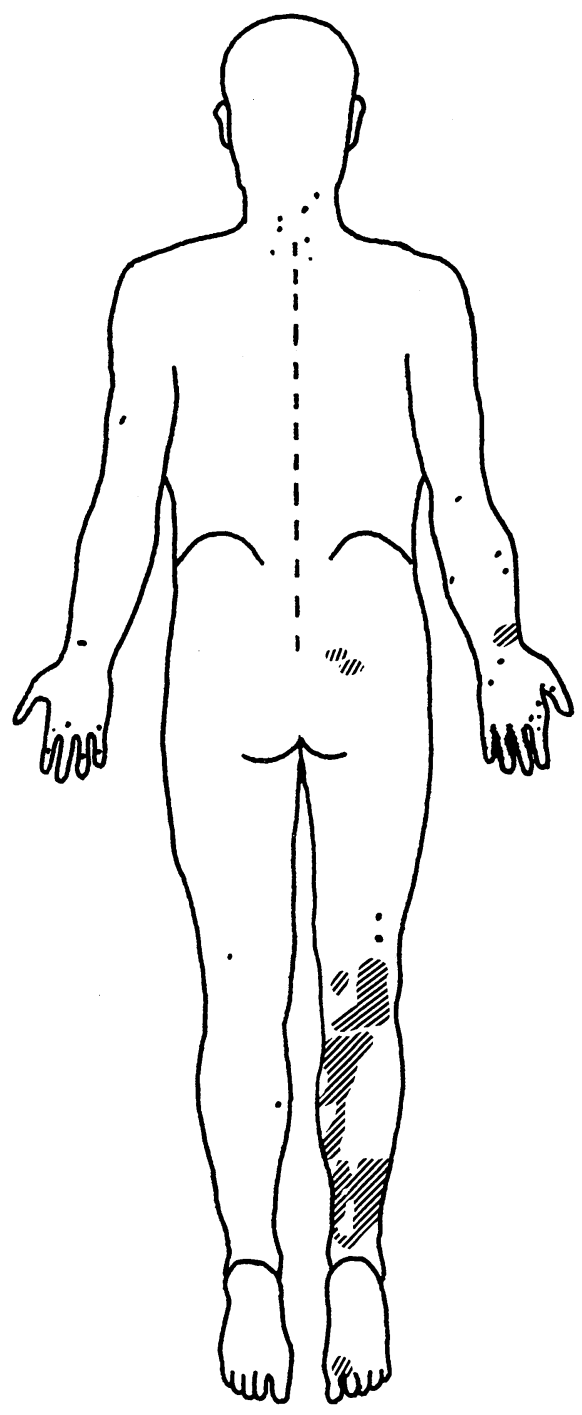

Fig. $1 \mathrm{~b}$ Distribution of leprous eruptions at the time of admission

診。

初診時所見は図 1 に示す如くで, 右眼の下の頓部と上 口唇に貨幣大, 浮腫状の隆起する紅斑, その他に左煩部 に小紅斑あり，口唇部の紅斑は知覚過敏，右下眼窩神経 に圧痛あり，鼻閉を訴える (Fig. 2)。右膝から下腿にか け手掌の倍位の大きさの紅斑あり，その内部に外見上健 常な部分あり，スイスチーズ様の外観を呈し境界群を思 わせる。この膝の皮疹には落屑あり, 知覚鈍麻す。右下 腿，右足脊の第 1 趾間に接した部分にも紅斑。右下腿の ものは殊に屈側に拈いて大きく，屈側の約半分を占め， 
その内部に外見的健常部を有す。それらの紅斑の境界は 比較的鮮明である。両手脊, 手指の伸側, 前腕, 下腿, 項部等に稗実大からレンズ大の, 境界鮮明な, 半球状に 隆起した硬い丘疹が散在していた。右前腕，臂部にも紅 斑あり，知覚鈍麻す。左手の尺骨側の部分の知覚鈍麻 す。右橈骨神経表在枝軽度に肥厚。運動麻㾇, 笳萎縮な し。皮疹よりの塗抹検査でらい菌は陰性。某病院で行な ったバイオプシーの標本は, 組織学的に類結核性の像を 示していた。

初診より直ちに治療開始。はじめ CIBA 1906を1日 $1 / 4$ 錠で週 5 日内服, それに Resochin $250 \mathrm{mg} /$ day と Minimax 3.0g/day の投与が行なわれた。1 週後 Resochin は在庫の関係から Ercoquin に切りかえられた。 また 1 週後より CIBA 1906は毎日1/4 錠になった。2 週後には皮疹のみずみずしさはとれてきた。7 月5 日左 手脊に浮腫を生じ,右後怪骨神経の神経痛が起ってきた。 一部の紅斑の表面に落屑を生じた。殊に下腿の皮疹で落 屑著明, 紅斑の紅色の色調なくなり褐色を帯びてきた。 右足脊から下腿にかけ知覚過敏。7月19日より左腕と右 足に神経痛様の疼痛を訴えた。同日より CIBA 1906を 1 日おきに $1 / 4$ 錠と $1 / 2$ 錠を交互にして毎日投与。少し 前に浮腫を生じ, 今神経痛様の疼痛を訴えているこの時 期に薬を増量したのにはやや問題があるが。 8 月 2 日右 下腿に 浅い潰瘍 2 個発生。皮疹の 落属著明。同日より CIBA 毎日 $1 / 2$ 錠に増量。 8 月 9 日より CIBA 1 日お きに 1 錠と $1 / 2$ 錠を交互にして毎日投与。潰瘍次第に拡 がる。また両下腿に新しい潰瘍発生。8 月25日潰瘍より の分泌物緑色を带びているので, 緑膿菌の感染を疑い入 院を勧告。翌26日細菌培養, 同定, 感受性の検査を提 出, 翌27日入院。9月13日に右前腕の鶏卵大の紅斑の中 央に潰瘍を形成した部分から潰瘍のない部分にかけて行 なったバイオプシーの標本の組織像もやはり類結核性の 像を示していた (Fig. 3)。即ち表皮下無変化層なしに表 皮直下より真皮の全層にわたり, 類結核性の病変で占め られ, 結締織は少し残存するのみ。類上皮細胞の集団と リンパ球の層が不整地図状にからみ合っている。そして ところどころに壊死巣があり，ラングハンス型巨細胞が かなり沢山みられる。表皮に近い部分の細胞は空泡を形 成しているものが多くみられる。らい菌は認められない。 9 月 4 日注射の光田反応は 48 時間值 $\frac{6 \times 8}{8 \times 11}, 2$ 週間值 $\frac{5 \times 5}{10 \times 10}$ (膿疱), 3 週間值 $\frac{7 \times 7}{7 \times 7}, 4$ 週間値 $\frac{6 \times 8}{8 \times 11^{\circ}}$ 。た 10月 1 日検査の皮疹の菌検査は 4 力所陰性, 1 力所で僅 かに 1 個の抗酸性菌を認めたのみ。以上の結果から類結
核型と判定されるが，ただ皮疹の所見からすると，皮疹 の数が多く，小さい皮疹がかなりあり，大きな皮疹は非 対称的であるが，小さい皮疹には対称的な分布がみら れ, 類結核型といら病理組織学的判定とやや食い違う所 見を示していた。潰瘍は右膝から下腿にかけての手掌の 倍位の大きさの皮疹の約 $1 / 4$ を占める不整形の潰瘍, 右 下腿屈側下半分を占める皮疹の約 $1 / 3$ を占めるもの, 同 下腿上半の皮疹の小部を占めるもの, 左下腿と右前腕の 鶏卵大の皮疹のうゔら豆大の潰瘍などであり，潰瘍底は 凹凸不平, 部分的に豚脂様の壊死部が付着しており, 皮 下穿掘はしていない(Fig. 4\&5)。潰瘍の分泌物の培養, 同定の結果は，緑膿菌は検出されず，Staphylococcus aureus が検出された。入院時のその他の臨床検査の成 績を示すと次の如くであった。

1) 血液検査

$\begin{array}{ll}\text { ヘマトクリット } & 35.0 \% \\ \text { 血色素 } & 12.28 / \mathrm{dl}(76 \%) \\ \text { 赤血球 } & 400 \times 10^{4} \\ \text { 白血球 } & 4.900 \\ \text { 栓球 } & 21.4 \times 10^{4}\end{array}$

白血球百分率

\begin{tabular}{|c|c|c|}
\hline 桿状核 & 4 & \\
\hline 分節核 II & 6 & \\
\hline III & 4 & 12 \\
\hline IV & 2 & \\
\hline 単球 & 2 & \\
\hline リンパ球 & 82 & \\
\hline
\end{tabular}

2) 肝機能検査

$\begin{array}{ll}\text { GPT } & \text { 26Karmen } \\ \text { GOT } & 53 \mathrm{mu} / \mathrm{ml} \\ \text { コバルト反応 } & 4 \\ \text { カドミウム反応 } & 8 \\ \text { チモール混濁試験 } & 1 \mathrm{U} \\ \text { 硫酸垔鉛試験 } & 10-12 \mathrm{U}\end{array}$

3）血液化学検查

$\begin{array}{lc}\text { 乳酸脱水素酵素 } & 144 \mathrm{mu} / \mathrm{ml} \\ \text { アルカリフォスファターゼ } & 75 \mathrm{mu} / \mathrm{ml} \\ \text { 総ビリルビン } & 0.4 \mathrm{mg} \% \\ \text { アルブミン } & 4.4 \mathrm{gm} \% \\ \text { 総蛋白 } & 7.8 \mathrm{gm} \% \\ \text { コレステロール } & 180 \mathrm{mg} \mathrm{\%} \\ \text { 尿酸 } & 6.0 \mathrm{mg} \mathrm{\%} \\ \text { 尿素窒素 } & 15 \mathrm{mg} \% \\ \text { ブドゥ糖 } & 100 \mathrm{mg} \%\end{array}$




$\begin{array}{ll}\text { 無機橉 } & 3.5 \mathrm{mg} \% \\ \text { カルシウムイオン } & 9.2 \mathrm{mg} \%\end{array}$

4）血清反応

CRP (-)

ASO 12Todd Unit

RAT (-)

5）梅毒血清反応

ワッセルマン反応 （一）

C. S. T. (-)

TPHA (-)

$\mathrm{RPCF} \quad(-)$

以上の成績をみると, 未梢血の検查で白血球の百分率 においてリンパ球が $82 \%$ といら異常に高い成績を示して いる以外には，特に記すべき異常は認められない。

入院してから CIBA 1906を止め，9月4日より DDS 毎日 $1 / 2$ 錠投与を開始した。以後 9 月 24 日より毎日 1 錠 に，10月 8 日より週 3 日は 1 日1.5錠，4 日は 1 日 1 錠 に，10月16日より毎日1.5錠に，11月 5 日から毎日 2 錠 に増量した。はじめのうち潰瘍は少しずつ良くなってい るようだった。10月 7 日二, 三の小さい褐色の丘疹が両 前腕に現われ，また左前腕の紅斑の周囲に数個の小さい 娘疹が現われた。他の皮疹も余り吸収しない。10月半ば より前腕の皮疹の一部が少し吸収しはじめてきたが, 極 めて僅かである。潰愓む中々良くならないので, 皮膚結 核の疑いをもち，11月20日より INH，PAS の投与を開 始した。INH 0.3+PAS 10.0/日を投与し, DDS は止 めた。しかし潰湯は余り良くならなかった。そこで診断 を確定する為に，右の足脊皮神経がやや肥厚しているの で，そのバイオプシーを行なった。その組織学的所見は 類結核性病変であり, 病変の著明なところでは, 中央に 著明な壊死が見られた(Fig. $6 \& 7$ )。この所見よりとも かく癩があることは確定した。INH, PAS は約 1 カ月 で中止した。12月25日より DDS を毎日 4 錠で投与し た。1月に入り皮疹も徐々に吸収し, 潰瘍も次第に縮少, 下旬には治瘱した。その後も時に極めて小さい潰瘍が生 ずることはあったが，2 月末にはそれもなくなった。皮 疹も多くは徐々であるが吸収して行ったが，両側手春に ある半球状に近く隆起した硬い丘疹だけは全く呼吸しな かった(Fig. 8)。そこで, 攋があることは前述の如く確 定したが，他の皮膚疾患の合併がありはしないかと考 え, その丘疹の一つのバイオプシーを行なった。なお丘 疹よりの塗抹検查で，核酸菌12個を見出した。組織学的 所見は, 真皮中層から皮下の表層にかけ, 結締織でよく 被包された大小の類結核性肉芽腫があり, その中央には
著明な壊死巣がある。巨細胞は少数(Fig. 9)。この組織 所見と，他の皮疹が吸収されつつあるのに，これら丘疹 が DDS 投与にも拘らず全く吸収しないことから, 皮膚 結核が癩に合併していないかといら疑いを再びもった。 先に述べた通り，攋があることは確定したが，皮膚結核 が合併しているのではないかという疑いをとく為に，バ イオプシーをした皮疹と同様の手脊の丘疹の一つを切除 し, 結核菌の培養試験を行なった。またツベルクリン反 応を行なったが，48時間值が $\frac{4 \times 4}{5 \times 5}$ であった。結核菌の 培養試験も陰性であった。皮膚科医の意見も求めたが, 前述の右前腕の潰瘍のある紅斑の組織所見は, 尋常痕瘡 の組織所見とよく似ているが, 皮疹の分布, 外観, 性状 等から尋常性痕瘡ではないと考えられ，また多見的に皮 疹に類似点のあるバザン硬結性紅斑や壊疽性丘疹状結核 疹はもつと組織学的に渗出性病変が強い。そしてこの例 のツベルクリン反応が弱い。また手春の丘疹の組織所見 と切除した神経の組織所見が極めて類似していることか らも，これは一元的に考えやはり癩性の病変であると考 える方がよいと思うとのことであった。また Sporotrichosis, Blastomycosis 等の真菌性皮膚疾患も一応考虑 に入れなければならないが，ヘマトキシリンエオジン染 色, メセナミン銀染色標本のいずれにも真菌を見出さ なかった。梅毒については前記の如く血清反応のいずれ もが陰性であるので除外しらる。Mycobacterium ulcerans による潰瘍も一応考虑に入れた。 $30^{\circ} \mathrm{C}$ での抗酸菌 培養は行なわなかったのであるが, M. ulcerans による 潰瘍は普通単発性であるということと組織像から，これ も除外した。

以上から本例は皮疹の肉眼的所見においては稍異型で あるが，類結核癩であり，その皮疹部に潰瘍を生じた例 であると断定した。そして本例に対しては，その後も DDS 毎日 4 錠投与を続けているが, 各皮疹とも徐々に 吸収しつつある。ただその吸収に速度の差があり, 隆起 も消失しよく吸収したものもあれば，手脊の丘疹の如く 吸収が極めて徐々であるものもある。その後は潰瘍の発 生を見ない。

mitogen に対する患者のリンパ球の反応性をしらべ た。Ficoll-Paque を用いて患者血液より分離したリン パ球を用い, マイクロテストプレートにより培養を行な った。PHA は各孔に $0.25 \mu 1$ 加え, 炭酸ガス培養器で $37^{\circ} \mathrm{C}$ で 3 日間培養した。細胞のとり入れの 24 時間前に ${ }^{3} \mathrm{H}$-チミジンを加えた。細胞のとり入れ後, 液体シンチ レーション・カウンターで計測した。その結果 Stimula- 


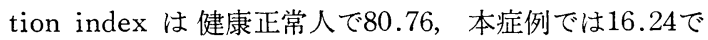
あった。

\section{考察}

本症例の病型は，皮疹の肉眼的所見からすると，かな り大きい皮疹もあるが，稗実大からレンズ大の小丘疹も あり, 数もかなり多く, 対称性に分布する傾向も一部に あり, また一部の皮疹は内部に外見上健常な部分があ り，その内部の境界も比較的鮮明で，以上の点からする と類結核型よりはむしろ境界群を思わせる。しかし塗抹 による菌検査は入院時陰性。入院後 1 力月余の検査でも 4 力所陰性, 1 力所で僅かに 1 個の抗酸菌を認めたのみ で，バイオプシーの組織所見も，入院前昭和 50 年 5 月 26 日某病院での皮疹のバイオプシー, 入院性同年 9 月 13 日 潰湯を形成した部分のバイオプシー，51年 3 月 5 日半球 状に近く隆起したレンズ大の丘疹のバイオプシーのいず れの標本も類結核性の像を示した。また50年12月12日に 行なった神経のバイオプシーも類結核性の病変を示し た。この点皮疹の肉眼的所見と組織所見の間にやや食い 違いが感じられたが, 組織所見を重くみて類結核らいと 診定した。後にのべる Ryrie が報告した症例も, 類結 核らいだが皮疹の数は多いとしておりこの点類似してい るが, Ryrie の症例の写真をみると境界群を思わせる皮 疹があり，のちにものべるように組織像でリンパ球の集 積がなく，かなりの菌が検出されて一部にグロービーが あることなどからすると, Ryrie の症例は純粋な類結核 らいではなく，境界群ではないかと思われる。

次に皮疹に潰瘍を生じた例の考察ということで，lazarine leprosy についてふれなくてはならない。lazarine leprosy については多くの混乱があるので, この 機会に lazarine leprosy についての文献をかえりみな がら，考察してゆきたいと思う。

lazarine leprosy という用語は，1852年メキシコの Lucio と Alvarado がらいのび漫性, 水疱性, 出血性 そして壊疽性の形を表わす為に用いたものであり，彼ら は“ “manchada”あるいは“lazarina”と呼んだ。 manchada というスペイン語は主に「斑（まだら）のあ る」といら意味を表わしている。彼らは lazarine leprosy を特徵づけるものとして斑紋, 潰瘍（水疮形成に

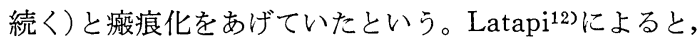
彼らは「皮膚の紅色有痛性の斑点」と重症性によって特 徴づけられるものとしていた。しかし Lucioらのこの 論文は，原著も抄録も現在利用できない。

$\mathrm{Wade}^{13)}$ によると, フランス人の軍医である Poncet
は1863年メキシコに配置され，そこでらいを研究する機 会を利用し，1864年にメキシコのらいに関して書いた。 ヨーロッパでメキシコ型の lazarine leprosy が全く無 視されるのを防いだのは Poncet である。Wade による と leloir は1886年にその著書の中で lazarine leprosy について繰返しふれ，それを神経らいの一つの像とみな していた。1897年 Zambaco Pachá は「コンスタンチノ ープルの断節らい」という題で, 水疮形成とそれにつゔ く痂皮と深い断節性潰瘍について記載した。Castelló と Caballero ${ }^{14)}$ はその一部を次のように引用している。「水 疮は破れ, あらゆる予防, あらゆる種類の局所治療, 内 服薬にも拘らず，その小さな潰瘍は周囲の組織に益々侵 入し, 直径数 $\mathrm{cm}$ となる。深い潰瘍をもった例では組 織は益々破壊され,腱は露出し,いくつかの例では一一幸 に稀であるが一一破壊的な過程は関節に拡がり, それを 止めようとするあらゆる試みにも拘らず,一つ一つ勒帯 を冒し,肢を離断してしまう。」そして殆んどの例でらい の他の症状はなく，ただ破壊的な潰瘍を呈するだけで, 結節も斑紋も他の栄養障害性の症状も何もないというこ とが特異であり，診断を困難にしているという。彼が報 告したこの型は, Castello らがのちに報告したものと 類似しており，メキシコの型とは異なるものである。

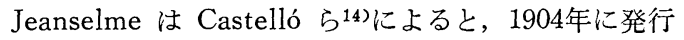
された有名な“Dermatologie exotique”の中に短か いが lazatine leprosy についてふれている。それには 紅斑の部位に現われる多くの天疮瘡をもつものとしてお り，アメリカことにメキシコに多いとしている。Caballero によると，同じく1904年に Guiteras らはキューバ で chappa という名称で呼ばれている lazarine leprosy と思われる例を報告している。Castelló らによると， 1913年 Isidore Dyer は，水疮は手や足の関節の部分に 繰返し生ずるとしている。1922年にキューバの Caballero は Latin-American Medical Congress に2 例の lazarine laprosy を提出した。前記の Guiteras の報 告したものは，殆どが Caballero の報告した型のらい である。Castelló らによると，1927年に Barrera と Chavarria は，ラテンアメリカで長い間知られ vejigón blanco と vejigón negro（白い水疮と黒い水疮）と呼 ばれている，らいにおける水疮形成とそれに続く壊疽を 報告した。1930年にキューバの Castelló と Caballero ${ }^{14)}$ は American Dermatological Association の年次総会 で, lazarine leprosyについてその時までの文献をか えりみながら，23例の研究に基ずいて 1 例の症例報告を 行なった。そして1931年に lazarine leprosy について 
の論文を発表した。それによると23例のすべてにおいて 症状と経過は同じで，一見全く健康な人にほぼ一ドル銅 貨大の紅斑が四肢の一つに現われ，そこに水疮が生ず る。水疮は破れ, 痂皮の下で潰瘍が進行し, 皮下組織,

筋。腱, 骨を破壊し, 関節は露出し断節に至る。痛みは 普通ない。23例中22例でらいの他の症候は見出されなか った。ただ 1 例において, 尺骨神経肥厚, 眉毛脱落, 痛覚 麻㾇等の典型的ならいの症状があった。潰瘍の分泌物か ら多数の抗酸菌が見出された。モルモットに膿や組織を 接種したが陰性であったといらから，人型あるいは牛型 結核菌ではないと考えられる。また寒天培地，血液寒 天, Petrowski 培地, 血清, サブロー培地にうえたが, ふつらの化膿菌が認められたのみという。しかし組織標 本で浸潤は結締織細胞とリンパ球と形質細胞からなって いるとあり，らい性の特有の像は認められていない。と いって抗酸菌が多数いたというから indeterminate で もない。また菌はあるものが細胞内にあったとあり，こ のことは細胞外にも多くの菌が認められたことを示し, このことも非らい性のものではないかといら疑いをおこ させる。培養温度は特に断ってないので, $37^{\circ} \mathrm{C}$ で行な われたと考えられ， $30^{\circ} \mathrm{C}$ でないと増殖しないで皮膚に 潰瘍をおこさせるMycobacterium ulcerans によるもの でないといら否定ができない。以上のことからこの23例 のうち, 他にらいの症状が認められなかった 22 例は果し てらい性のものであったのかといら疑いが残る。しかし Wade は次のように記している。「のちの会合において 1 例の lazarine leprosy が提出され議論されたが，そ の際 Castelló が次のようにのべていることは興味深い。 即ち以前 Caballero がはじめて lazarine leprosyの 症例を提出したとき, Castelló はそれは慢性の亜性の 潰瘍であると信じ，らいというその診断を受け容れるの を拒絶したといら。しかし Klingmüller は切片の所見 からそれをらいと診断した。切片に拈いてその神経の中 に抗酸菌を認め, そしてハーバード医学校でなされた培 養と動物接種は陰性に終った。H. Fox も彼の旅行にお いてそのよらなものは全くみたことがないとのべ, Hopkins と同様，彼はその症例をらいと診断することがで きなかったといった。」神経の中に抗酸菌を認めたと いうことからすると，その例は確かにらい性のものであ ったといってよい。

1935年マニラの Rodriguez ${ }^{15)}$ は lazarine leprosy について記し, らいのこの変種の特徴は, 紅斑や孤在性 の結節や四肢の厚皮性の浮腫から生ずる水泡の形成を伴 なうところの, しばしば病気の初期におこる速やかな進
展である。そして水疱が破れると速やかに拡がる潰瘍あ るいは壊死域が現われる。それらが皮膚, 筋肉, 腱を破 壊し, 関節を露出させ, すさまじい組織の破壊と変形に 終ると記している。この点で Rodriguez の記載は, Zambaco Pachá の記載ならびに1931年の Castelló と Caballero の記載とよく一致する。ただ Rodriguez に よると, 組織学的には典型的な類結核型であるという。 ただ普通類結核型では菌が少数なのに, lazarine leprosy の病巣には菌が沢山いるという。

1938年 Ryrie11は “Acuae ulcerative or sloughing tuberculoid leprosy” といら題名で, 1932年以来20例 をこえる潰瘍形成例が Sungei Buloh で治療されたと のベ，この論文では最近の1例について記している。こ の過程は急性類結核らいの普通の flare up または反応 ではじまる。Castelló らの症例が monosymptomatic で他のらい症状がないのとこの点は異なる。類結核型の 病巣は多発性である。また潰瘍の数が多いことも Castelló らの症例とは異なる。潰瘍形成の過程としては, はじめ落屑を生じ次で潰瘍を生ずるものがもっとも普 通で, 時に水疮を生ずるものがある。この点水疮形成次 で潰瘍形成が主症状である Pachá あるいは Castelló らの症例とやや異なり, 落屑形成次で潰瘍形成が主であ る。進展した潰瘍の深さは $1 / 2 \mathrm{~cm}$ 以上あるといらが, Pachá やCastelló らの報告した症例の如く破壊的では ない。バイオプシーでは reactional tucerculoid の像 を示しているとしてあり, 塊状の肉芽腫で, 主成分は類 上皮細胞であり，多くの巨細胞がみられる。また多くの 末分化の細胞があり, リンパ球の集まりはない。泡沫細 胞はないが，しかし往々グロービーを含んだ細胞が見ら れたと記されている。皮疹の写真をみると境界群を思わ せる皮疹があり，また皮疹の数が類結核型にしては多 く，小さい皮疹がかなり数多くあり，また組織像でリン パ球が余りなく，かなりの菌が検出されて一部にグロー ビーがあることなどからすると，この症例も純粋な類結 核型ではなく境界群ではないかと思われる。

Castelló と Piñeyro(16)によると，1939年に Vespoli は lazarine leprosy について記し，紅斑に始まり，速 やかに組織の破壊に進む水疱性そして潰瘍性の状態とし て記している。そして類結核型の像を示し，ふつう壊死 部に無数の菌がいるとのべている。

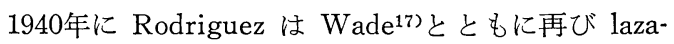
rine leptosy の閒題を回顧し，1例の水疮次で潰瘍を 形成した症例を報告した。この症例は類結核型としてあ る。しかしはじめ minor tuberculoid lesion があった 
としてあるが，菌が多数ということから TT ではなく Bに傾いていたと思われる。はじめに小類結核性病巣が あったということは, monosymptomatic である Castelló らの症例と異なる。そして彼らのいら第 4 期にお いてあらわれた皮疹の記載をみると，典型的な類結核型 とは異なっており，皮疹の外縁はゆるやかに傾斜し，内 縁は急に境されているということ，菌が強陽性であるこ と，そして組織学的に類結核性の状態を示すものはな く, むしろ大変活動性の nonfoamy lepromatous one を思わせるものがあるといらことなどから，これは境界 群であったと思われる。神経肥厚も対称的で, 運動麻瘏 も両側性であることからも，類結核型ではないと思われ る。そして約半年後の検査では, 潰瘍のできなかった顔 の皮疹は殆ど消退して認めにくくなっており，菌検查で ははじめ菌が多数いたといらのに，半年後では 4 力所陰 性で 1 力所が 1 +であったという。こういう経過からす ると，Bにおこった reversal reaction であったのでは ないかと思われる。そして半年後のバイオプシー所見は 類結核性であったという。

1941年に Burks と Brunsting ${ }^{18)}$ は，らい腫型の若い メキシコ人における水疮形成の 1 例を報告した。その症 例は, Lucio と Alvarado が，そして後に Latapi ら が報告した症例に似ている。

Castelló と Piñeyro ${ }^{16)}$ にると，1941年に Fernandez Vautrai は批判的な文章で lazarine leprosy について 考察し,メキシコでみられる Lucio 型, Rodriguez と Wade が報告した症例，そしてキューバの学者が報告し た症例についてのべ, “lazarine leprosy”という言 葉は，らいの特殊な型を示すのに用いるべきでないと結 論した。Cartelló と Piñepro によると，1944年に Bechelli, Rotberg および Maurano はブラジルで発行さ れた論文の中に類結核らいの患者に扔けるらい性天疱瘡 をのべており，彼らの記載は lazarine leprosy のそれ とよく一致している。

Lucio と Alvarado のすばらしい記述にも拘らず， 彼らの lazarine leprosy という命名は誤解され，メキ シコにおいてさへ彼らの仕事は徐々に忘れられた。1938 年に Latapi はこの型を再び分別した。そして Lucio's leprosy はメキシコのすべてのらい学者によく知られる ようになった。1948年 Latapi とZamora ${ }^{12)}$ は，Lucio’s leprosy の臨床像において最も本質的な事実で, Lucio が気付いていなかったものをしらべた。それはこの臨床 型における基本的な条件は diffuse, generalized cutaneous condition であるという事実であるとし，それは
今日のらい腫型に属するものであり, “ pure and primitive diffuse lepromatosis (Lucio and Alvarado, 1852)" と名付け, Lucio らのいう“ “red and painful area”は“Lucio’s phenomenon”，あるいは結節性紅 斑と多形性紅斑と類似のものであるとして “ erythema necrotisans" と命名した。そしてそれは多発性の急性 の壊疽化性の血管炎によってつくられるらい反応の一種 とみなしている。彼らによると，メキシコ市で彼らがみ ている患者の15 20\%に Lucio 型を 観察しているとい う。広範囲な潰瘍化と悪液質的な状態を伴なって $2 \sim 3$ 年以内に死ぬ多くの例が観察されている。スルフォン治 療を始めると，短期間に治る例も経験されている。これ らの例は秃頭, 盾睫毛の脱落, 梅毒血清反応の偽陽性な どから，らい腫型であると判断される。

1949年 Castelló と Piñeyro'16)は, メキシコ人の症例 が，Castelló と Caballero がキューバで観察し報告し た症例とは全くちがっていることを指摘した。メキシコ 人の患者は典型的ならい腫らいであり, 水疮の形成, 浅 い潰瘍の形成がおこる。Pachá が報告した症例やキュー バ人の症例にみられる深い潰瘍や断節を決して起こさな い。キューバの症例では水疮が多数であることは稀だ が，メキシコの症例では数が大変多い。Pachá の症例や キューバ人の症例は monosymptomatic であるが, メ キシコの症例はちがう。組織学的には，メキシコの症例 はらい腫らいの組織像であり，顕著な血管病変を伴ない 壊死に終る。しかしキューバの症例では中心壊死を伴な った類結核性である。菌は壞死部に大変多いが，周囲の 組織では少数または欠如している。レプロミン反応は常 に陽性。な打病変部をモルモットの皮下，皮内，腹腔内 にうえたが陰性。抗酸菌培養の試みも陰性であったとい う。結論として Castelló と Piñeyro は, lazarine と 呼ばれるらいの特殊な型はないといっている。

1949年 Romero ら ${ }^{19)}$ は Casta Rica でみられた Lucio 型のらいを報告している。Wade によると, Dharmendra は Lucio 型のらいを見にメキシコに行ったが，そうい う例をインドや彼が訪れた他の国では決してみないとい っている。インドでは “diffuse” lepromatous case は大多数のらい学者にとって全くありきたりのものとし て見過ごされているのだが。

1949年 Wade ${ }^{13)}$ は “The 'Lucio' and 'lazarine' forms of leprosy” という題名の論文を書いている。 キューバとメキシコの lazarine leprosy について過去 の文献を顧み, 結論として Latapi らが与えたらい腫ら いにおける Lucio leprosy という名称が, メキシコの 
型について使われ続けるだろうとし, Lucio らが記載し た症状の命名としての lazarine といら言葉は, もはや 必要でないし不適当であり, lazarine という言葉は neural leprosy における bullous-ulcerating condition を表わす為に使うのがよいと思うとのべている。

以上過去の文献をひもとくと, lazarine leprosyに ついて多くの混乱があることが分る。 lazarine leprosy という用語を始めて使ったのは, 上述の如く Lucio と Alvarado であり，それはらい腫らいにおける水疱次で 潰瘍形成を特徴としていたのであるが，同じような特徴 があるといらことから，類結核型における水疱形成そし て潰瘍形成をも意味することになった。こうした混乱 は，一つには古い時代に打ける病型分類の未熟さにもそ の原因があったのであり，“cutaneous”といら病型の 古い命名が示すように，皮疹を生ずるものが長いこと同 一視されていたわけであり，こうした混乱が起ったのも やむを得なかったことと考えられる。とにかく水疱に次 で潰瘍を形成するといら特徴をもつものが同一視されて しまったわけである。そしてらい腫らいにおこるメキシ コ型の lazarine leprosy と, 類結核らいまたは境界群 におこるキューバ型の lazarine lestosy とができてし まったわけである。そして一時は本来のメキシコ型のも のより，キューバ型のものの方が文献的に主流をなして しまった。そしてさらに Rodriguez が報告した症例は’ Pachá や Castelló と Caballero が報告した症例に似 ているが，Rodriguez 自身も言っているように，同じと はいえない。Pachá や Castelló らの症例は monosymptomatic であるが，Rodrigue の症例は，はじめに明 らかならい性の皮疹が存在しており, monosymptomatic ではない。また Castelló らの症例の組織所見は明らか な類結核性の像を示していない非特異的な像であるが, Rodriguez の例は類結核性の像を示していたという。た だしかし Rodriguez の報告をみると，その症例は前に 記したように類結核性というより今日の分類でいうと境 界群であったと思われるが。そして Rodriguez の報告 についで Ryrie の報告がでてくる。Ryrie 自身はその 報告中に lazarine leprosy という言葉は使っていない が，のちに他の人によって書かれた lazarine leprosy についての論文中には, Ryrie の報告も含まれている。 Ryric の症例は Rodriguez の症例に似ていて, やはり monosymptomatic ではなく, 病型も Ryrie は類結核 型といっているが, やはり今日でいう境界群であったと 思われる。しかし Ryrie の症例は，水疱を形成するも のもあるが, むしろ速やかに進展する落屑形成が普通の
様式であり，また潰瘍を形成しても，Pachá や Castelló らや Rodriquez らの症例のように破壊的に深部へ波及 するということはない。

以上のように, lazarine leprosy と呼ばれるものに は，いろいろな性質のものが混在している。それらに共 通した唯一の点は潰瘍形成といらことになってしまう。 このように性質の異なったものを，今日 lazarine leprosy として一括することは到底無理である。しかし Wadeのいらように, lazarine leprosy という名称を, 本来その名称をはじめて使った Lucio らの報告したら い腫らいのメキシコ型のものに用いないで，キューバ型 のものに用いるというのも，いささか無理な感じがす る。むしろ今後とも lazarine leprosy という言葉を使 うことは混乱を招くので，二つの異なった型のものに， それぞれの最初の報告者の名を冠して, Lucio's leprosy と Pachá's leprosy と呼ぶのがよいのではなかろらか。 この意味では，Ryrie の報告した型のものを特に分ける 場合は, Ryrie’s leprosy と呼べばよいであろう。

今回の著者らの例が類結核型であり, monosymptomatic ではなく, 落屑形成があり次で潰瘍が形成された点, 潰瘍が破壊的ではないという点，皮疹が類結核性である のに数が多いといら点などから，今回の例は上記の諸報 告のうちでは, Ryrie の症例に最も似ている。ただ少し異 なる点は，組織所見で Ryrie の症例は前にも記したよ らにリンパ球の集まりがなく，未分化の細胞があり，か なりの菌が検出され一部にグロービーがあるなど境界群 を思わせるが，今回の例には多くのリンパ球がみられ， 菌は認められず,類結核性の像を示していたのが異なる。 また今回の例は太田・佐藤3)の報告中にある潰瘍形成例 ともよく似ている。太田らの例ではリンパ球も沢山あり, 類結核らいと考えられる。少し異なる点は, 太田らの例 では皮疹が右膝にいくつかあるのみであるが，今回の例 では皮疹の数が多く，丘疹などは対称的なものがあった という点である。潰瘍形成の前に落屃があったかあるい は水疮形成があったかなどは記載がないので分らない。

本例のように類結核らいで皮疹に潰瘍を生ずるのは， 個体の細胞免疫が異常に杗進し, 恰かも光田反応の局所 に, 反応が強陽性の際には水疮, 膿疮, 潰瘍を生ずるが 如くに, 組織反応が強すぎる為に壊死を生ずるのではな いかと考え, 免疫学的諸検査を計画したのであるが, PHA-P に対するリンパ球の反応性しかここに利用でき ないのは残念であるが，予想に反して患者のリンパ球の 反応は健康正常人よりもむしろ低い值を示した。 


\section{文献}

1)塩田広重：神経癩の末梢神経中に於ける結核㥞 変化の梗概. 中外医事新報， 755， 1201-1204 (1911).

2）小笠原登，二宮茂茂弥：癩性神経膿瘍について。 皮膚科紀要，25，337-342（1935).

3）太田正雄, 佐藤三郎：癩の結核様変化に就いて レプラ，6，513-532 (1935).

4）宗内敏男：癩の病理。治療及処方，223，17261732 (1938)

5）佐藤三郎：癩に於ける末梢神経殊に皮疹内微細 神経線維の病変に就て。レプラ，17，15-20 (1948).

6）犀川一夫：結節癩の娘より感染せし斑紋瀨老母 に見たる稀有なる多発性神経膿湐の1例．レプ ラ, 19, 4-6 (1950).

7）犀川一夫：癩の種々相に於ける末梢神経の病理 組織学的研究 (1) 斑紋癩, (2) 斑紋吸収期（初 期神経癩)。医療，5，1-4 (1951).

8）平島宰三：乾酪性膿瘍を形成した為尺骨神経腫 瘍を思わせた神経癩の一例. 大阪医科大学雑誌, 12, 98-100 (1951)

9）佐藤三郎，谷村忠保，桜根太郎：癩. 日本皮膚 科全書, 第 9 巻, 73 (1954) 金原出版, 東京.

10) J. Lowe: A study of macules in nerve leprosy with particular reference to the "tuberculoid " macule. Leprosy in India, 8, 97112 (1936).

11) G. A. Ryrie: Acute ulcerative or sloughing tuberculoid leprosy. Internat. J. Leprosy, 6,
153-165 (1938).

12) F. Latapi and A. C. Zamora: The "spotted" leprosy of Lucio. (La lepra "manchada" de Lucio) An introduction to its clinical and histological study. Internat. J. Leprosy, 16, 421-437 (1948).

13) H. W. Wade: The "Lucio" and "lazarine" forms of leprosy. Internat. J. Leprosy, 17, 95-102 (1949).

14) V. P. Castelló and G. M. Caballero: Lazarine leprosy. A peculiar monosymptomatic form of leprosy. Arch. Dermatol. Syphilology, 23, 1-11 (1931).

15) J. N. Rodriguez: Lazarine leprosy. Lepr. in India, 7, 152-155 (1935).

16) V. P. Castelló and R. Piñeyro: Lazarine leprosy. Its position in the present classification of leprosy. Internat. J. Leprosy, 17, 6571 (1949).

17) J. N. Rodriguez and H. W. Wade: Bullous tuberculoid leprosy. Report of a case, with a discussion of lazarine leprosy. Internat. J. Leprosy, 8, 333-345 (1940).

18) J. W. Burks and L. A. Brunsting: Lazarine (pemphigoid) leprosy; report of a case. Proc. Staff Meet. Mayo Clinic, 16, 488-492 (1941).

19) A. Romero, A. B. Ibarra and M. Fallas: Clinical study of lepromatous leprosy in Costa Rica. Internat. J. Leprosy, 17, 27-33 (1949). 


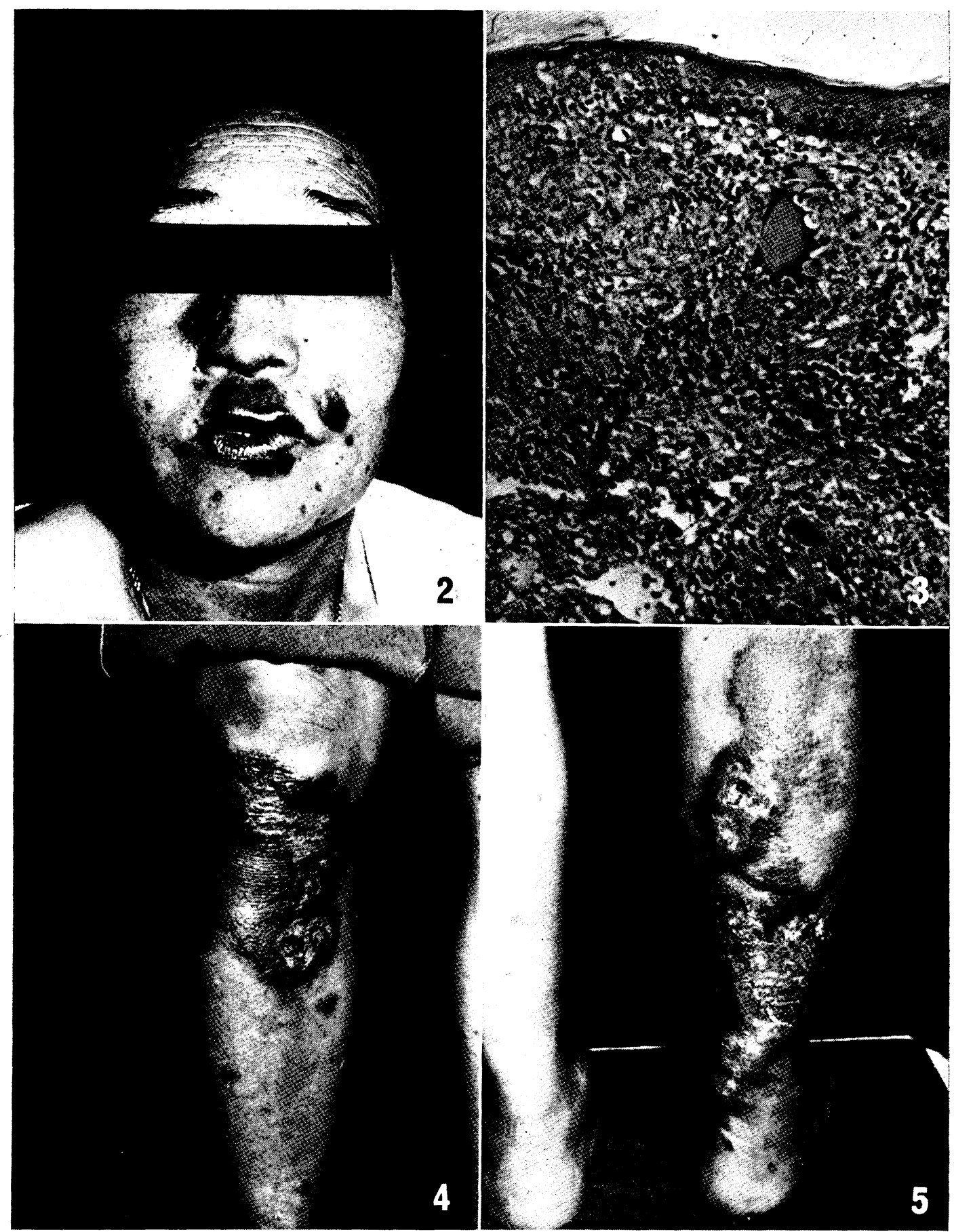

Fig. 2 Erythemata on the face. When this picture was taken, the erythemata were rather absorbed, and their redness and rising were reduced.

Fig. 3 Tuberculoid change of an erythema on the right lower arm

Fig. 4 Ulcer of the patch on the right knee. When this picture was taken, the considerable part of this ulcer was already healed.

Fig. 5 Ulcers of the patches on the right leg 


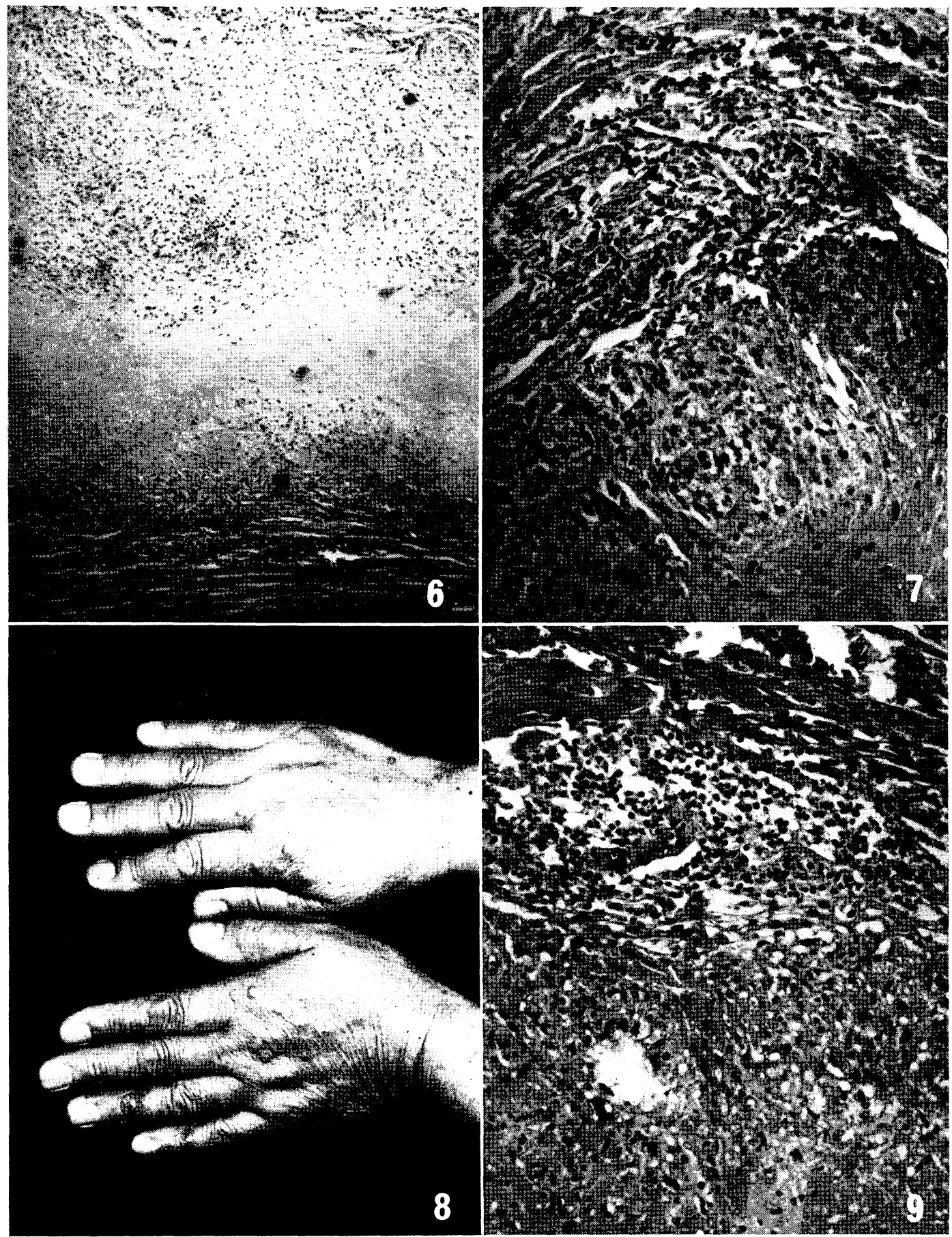

Fig. 6 Tuberculoid change of a nerve

Fig. 7 High magnification of the tuberculoid change of a nerve

Fig. 8 Papules on the back of both hands and fingers

Fig. 9 Tuberculoid change of a papule on the back of right hand 